\title{
Editorial
}

\section{Air travel (Problem in high altitude)}

\author{
MY Ali
}

Exposure to high altitude has become a common event as a result of developments within the last century including air travel, mountaineering and even tourism. The physiological effects of high altitude are very significant. Barometric pressure falls in high altitude. With the fall in barometric pressure, the proportion of oxygen, nitrogen and carbon dioxide in air don't change, but the pressure of each of these falls in proportion to barometric pressure. Oxygen tension within the pulmonary alveoli is further reduced at high altitude because the partial pressure of water vapour is related to body temperature and not barometric pressure, and so is proportionately greater at high altitude ${ }^{1}$.

Commercial aircraft usually cruise at 10,000- 12,000 metres, with the cabin pressurised to an equivalent of around 2400 metres. At this altitude $\mathrm{PaO}_{2}$ is $16 \mathrm{kPa}$, $(120 \mathrm{~mm} \mathrm{Hg})$, leading to a $\mathrm{PaO}_{2}$ in healthy people is 7.0-8.5 kPa. $(53-64 \mathrm{~mm} \mathrm{Hg}) . \mathrm{O}_{2}$ saturation is also reduced, but to a lesser extent. Although well tolerated by healthy people, in patients with respiratory disease this degree of hypoxia may be dangerous. The resulting hypoxia causes breathlessness in those with severe cardiorespiratory disease ${ }^{2}$. In addition, the reduction of barometric pressure at high altitude leads to increase in gas volume within body cavities.

With respiratory diseases who want to fly, specialist pre-flight assessment is advised for all patients who have hypoxaemia $\left(\mathrm{O}_{2}\right.$ saturation $\left.<95 \%\right)$ at sea level, and include spirometry and a hypoxic challenge test with $15 \% \mathrm{O}_{2}$. Air travel may have to be avoided or be undertaken only with inspired $\mathrm{O}_{2}$ therapy during the flight. Asthmatic patients should carry the inhalers. Following pneumothorax, flying should be avoided while air remains in the pleural cavity.

Other patients like cardiac dysrhythmia, IHD and sickle- cell anaemia, who are more susceptible to hypoxia, require individual assessment. Pregnant woman should avoid air travel after 36 weeks of gestation and complicated pregnancy should avoid it at an earlier stage.

Dr. Md. Yusuf Ali, FCPS (Medicine), Associate Professor, Dept. of Medicine, FMC, Faridpur.
Patients, who have had recent abdominal surgery, including laparoscopy, should avoid flying until all intraperitoneal gas is reabsorbed. Ear and sinus pain are common, due to change in gas volume but usually mild. Patient with chronic sinusitis and otitis media may need special assessment on long flights. The patients with DM may need to adjust their insulin or oral hypoglycaemic drugs dosing according to the timing of preflight and subsequent meals.

Air travelers have an increased risk of DVT, due to factors including loss of venous emptying because of prolong immobilization and decrease barometric pressure on the tissues, together with haemoconcentration as a result of oedema and perhaps a degree of hypoxia- induced diuresis. This can be prevented by avoiding dehydration and exercising of muscles during the flight ${ }^{1}$.

\section{References}

1. Hanlon P, Byers M, Walker BR, Summerion C. Environmental and nutritional factors in diseases. In: Davidson's Principles \& Practice of Medicine. Boon NA, Colledge NR, Walker BR, Hunter JAA, Editors. 20th edition. Churchill Livingstone, Edinburgh, 2006. P.103-6.

2. Hackett PH, Roach RC. High altitude illness. New England journal of Medicine, 2001; 345: 107-114. 